\title{
The Effect of Adaptive Selling on the Salespeople Performance of Life Insurance Mediated by Customer Orientation
}

\author{
Eko Hartanto $^{\text {a }}$ Fawzia Aswin Hadis ${ }^{\mathrm{a}}$, E. Susy Suhendra ${ }^{\mathrm{a}}$, Anita Zulkaida ${ }^{\mathrm{a}}$, \\ eko hartanto@staff.gunadarma.ac.id
}

aPostgraduate School, Gunadarma University, Jakarta, Indonesia

\begin{abstract}
The development of information technology is increasingly massive in the hope of having an impact on all aspects of life. However, the activities of insurance companies in offering their products to individuals or groups, still require a direct relationship between their marketing personnel in a face-to-face manner. The purpose of this study is to "test whether the theoretical model of salesperson performance in terms of adaptive selling and customer orientation as a mediator variable is compatible with empirical data. This study is a quantitative study with a sample of 275 life insurance salespeople who have more than 2 years of experience and have a life insurance salesperson's license. Data collection using purposive sampling and snowball sampling. The measuring tools used are adaptive sales scale, customer orientation scale (SOCO) and salesperson performance scale. The analysis method uses path analysis, with the AMOS program. The results of the path analysis illustrate that the research model tested is in accordance with empirical data, meaning that the research model of the Effect of Adaptive Sales on the Performance of Life Insurance Salespeople Mediated by Customer Orientation has conformity with empirical data and meets the requirements of goodness of fit. The results show that customer orientation is an adaptive selling mediator variable on the performance of life insurance salespeople.
\end{abstract}

Keywords: adaptive selling, customer orientation, salespeople performance, life insurance.

\section{Introduction}

Life insurance is a tool to mobilize savings, so it is hoped that it can raise public funds for a long time and become one of the pillars of the national economy. However, compared to the banking industry, the insurance industry lags far behind in raising public funds, despite improvements in insurance products, such as the combination of investment and protection. Insurance product innovation has not solved the problem of low public participation in insurance in the insurance industry. According to Indonesian Banking Statistics data (OJK, 2020), public funds collected by the National Bank have reached around Rp. 6,665 trillion, with a total of 303,132,916 customers, while the premium for life insurance according to the 2020 AAJI report is Rp. 215.42 trillion. This figure shows that compared to the number of policyholders and bank customers, there are fewer individual and group life insurance policyholders, namely 17,312,740 policyholders.

This phenomenon is still very low compared to public attention to insurance in other countries such as China. Chinese residents can use $25 \%$ of their income for insurance, while Indonesian residents use less than $1 \%$ of their income for insurance. At the same time, with a population of around 270 million, the Indonesian insurance industry has considerable potential, because around 200 million people of the total population of Indonesia have the possibility to purchase insurance. But in fact, only about 17 million people have individual insurance policies (AAJI, 2020). Likewise, the implementation of the National Health Insurance Program is managed by StateOwned Enterprises as providers of health insurance known as BPJS Kesehatan. No more than 20 percent of Indonesian citizens have to pay their own dues and are registered voluntarily (BPJS Kesehatan, 2017). Although it is a mandatory program for every Indonesian citizen, the public's willingness to register for the National Health Insurance is still low. Another problem with regular premium payments is that most people only pay premiums when they are sick and never pay them back after recovering.

The problem of the insurance industry is in dire need of continuous handling, starting with the need for research on the low interest of the public to have an insurance policy and improving the performance of insurance companies. Several studies (Yu and Chen, 2014; Aslam, Ilyas, Imran and Rahman, 2016; Putri and Ernawati, 2019) found that an effective insurance agent or salesperson will deliver insurance benefits, thereby creating insurance demand. Also, the greater public interest in insurance, the higher the premium paid, which can improve the financial performance of the business.

The sales force for the company is the spearhead who has an important role for the company, because the ups and downs of the company's performance are highly dependent on the performance of the sales force, this is in recognition of the fact that the sales function is very important for the success of the organization, many researchers since the 1900s have identify factors that influence salesperson performance and company sales 
effectiveness (Babakus et al., 1996; Churchill et al., 1985; Cravens et al., 1993; Piercy et al., 1999). The same results are also obtained from recent research on salesperson performance and marketing effectiveness such as the results of studies by Nwokah and Ahiauzu (2009), Yu and Chen (2014), Aslam et al (2016), Alnawas and Brown (2017), Tseng (2018) can reinforce the importance of sales force capabilities in the success of the insurance industry. The study is based on Tseng's (2018) research, where the sales performance model is conceptualized as a consequence of the role of the salesperson, and other factors including the company's organization and the environment and its changes. It can be said that the salesperson's performance is the accumulation of the results obtained by the salesperson in carrying out his activities, and the salesperson can be declared to have good performance if he has been able to meet the targets set by the company.

Researchers generally agree that customer satisfaction is a key factor in determining long-term business success (El Samen and Akroush, 2018; Yu and Chen, 2014; Tseng, 2018; Alnawas and Brown 2017; Miti, Perkio, Metteri, and Atkins, 2020). The salespeople that customers contact the most have been identified as important determinants of the extent to which customers get satisfaction (Tseng, 2018). Since the salesperson is an important determinant of customer satisfaction, it can be said that the level of customer orientation for the salesperson will be an important factor in determining the level of customer satisfaction. Such an argument is based on the fact that salespeople who have higher levels of customer orientation will have higher customer satisfaction ratings (Aslam et al 2016; Tseng, 2018; Miti et al, 2020).

Every prospective client has different needs and wants. This means that adaptive sales are needed for salespeople, especially insurance salespeople, because the different characters of prospective customers or customers require insurance salespeople to adapt themselves to the conditions and situations that exist in the field, both how to serve and how to communicate with prospective customers. Adaptive sales, namely sales that adapt to customer needs and expectations. Adaptive selling ability is absolutely needed by insurance agents because the insurance agent will face potential policy buyers (prospects) with very varied characteristics and needs. An insurance salesperson is required to be able to adapt to the characteristics and needs of prospective customers.

The reality in the field shows that the quality of human resources and the service approach of salespeople to consumers in Indonesia (including life insurance) is still relatively lacking (Roesanto, 1996 in Yudiani, 2005). Increasing the ability to sell adaptively by insurance agents is a logical consequence of the current conditions, considering that insurance products are difficult to sell because they are intangible products, namely products that can be enjoyed in the long term. Products like this cannot be offered in the form of mass promotions, because each type of insurance product is specific for each person (personal selling). Therefore, the presentation of information about insurance to prospective customers must be specific and direct for each prospective customer (Stanton, 1999).

The adaptive selling ability of insurance agents cannot be formed by itself, but there are factors that influence it. Adaptive selling is influenced by many factors, namely self-monitoring, androgyny, empathy, openers, control center, intrinsic orientation, cognitive type, experience, job interest orientation, and supervisor management type (Spiro \& Weitz, 1990; Goolsby, et al, 1992). ; McIntyre, et al, 1996).

Salesperson performance refers to the financial and non-financial achievements achieved by individual salespeople in relation to their roles and responsibilities as determined by the company. It indicates how well the salesperson performs in carrying out his related sales duties while carrying out his assigned job responsibilities (Babakus, Cravens, Grant, Ingram, \& LaForge, 1996). Meanwhile, the research conducted by Wong (2016) found that adaptive behavior has a significant effect on improving the performance of salespeople.

The ability or performance of a salesperson can increase if a salesperson has a high adaptive sales behavior, namely by using different sales approaches appropriately during transactions with customers and when making decisions during sales transactions for different sales situations. Spiro and Weitz (1990) in Kavoosi, et al (2014) define adaptive selling behavior as consisting of gathering information about prospective customers, developing sales strategies, evaluating the impact of messages, and making adjustments (in sales presentations) based on evaluations. In fact, adaptive selling behavior is the ability of the seller to meet his operations with the shared needs of the buyer (Keillor and Parker, 2000).

\section{Literature Review}

Insurance Salesperson

Article 45 paragraph (1) Regulation of the Financial Services Authority (POJK) Number 23 of 2015 concerning Insurance Products and Marketing of Insurance Products stipulates that marketing of insurance products can only be marketed through four channels, namely direct marketing, insurance agents, bancassurance, and agencies. businesses other than banks.

Insurance salesperson/agent is a person who works alone or works for a business entity, who acts for and on behalf of the Company and fulfills the requirements to represent the Company in marketing Insurance Products. (OJK, 2019) 
Judging from the meaning of the article above, an insurance agent is a person who works to market insurance products for and on behalf of insurance companies. Which means the Insurance Company authorizes the agent to act and the agent must not exceed the power limit given by the company.

The agent's relationship with the insurance company is maintained in an agreement called the "Agency Agreement", the agency agreement can be in the form of a standard or standard agreement issued by the Agency Department and made by the insurance company. only agree and accept what has been determined by the insurance company.

\section{Insurance Salesperson Performance}

Performance is the most widely studied standard variable in the organizational behavior and human resources literature. Performance as a construct may be more important in a sales context, as salesperson performance often has a direct effect on company revenue.

The success of a company depends on the company's internal factors. Internal factors are influenced by the quality of salespeople and the performance of sales management which are the company's priorities. The success of the company's performance is measured by the total number of sales, the increasing portion of the target market, costs, the contribution of the company's profitability, and customer satisfaction (F.L.Chung, 2011).

According to Verbeke, Dietz \& Verwaal (2011), sales performance is used as an ingredient in evaluating the sales contribution of salespeople in achieving company goals. Performance is the behavior of salespeople, with various strategies as a form of responsibility for their work. The strategy used by the salesperson shows the behavior of the sales force and the results that have been obtained from the sales effort. Aspects of experience and expertise of salespeople as a driving factor of sales performance, which has a positive influence on increasing sales performance. Expertise in sales activities/activities is a necessity that must be possessed by a salesperson, because expertise is an important issue to deal with consumers and companies.

The sales force performance scale is measured based on the sales force performance indicators compiled by Park and Deitz Y (2006), namely: (1) Generating high market share for companies in certain regions, (2) Generating sales on products that provide the highest profit margins, (3) Generate sales in currency units at a high rate, (4) Retain priority customers, (5) Find and build relationships with new customers.

\section{Adaptive Selling}

Kavoosi, (2014) defines adaptive sales behavior as consisting of gathering information about potential customers, developing sales strategies, evaluating the impact of these messages, and making adjustments (in sales presentations) based on these evaluations. In fact, adaptive selling behavior is the ability of the seller to fulfill his operations with the shared needs of the buyer (Keillor and Parker, 2000 in Kavoosi, (2014). Adaptive selling behavior is the ability of the salesperson to use different sales approaches according to the sales situation faced and the type of customer. found (Indriani, 2005). According to Manske, et al., (2005) sales force adaptivity is the practice of changing a sales behavior based on consumer reactions and natural situations in sales. A salesperson is said to have a high level of sales force adaptivity if he can use different sales approaches appropriately when dealing with customers and when making decisions. The level of adaptability of the sales force requires a highly skilled and trained workforce who can interpret sales situations and then adopt and sales tactics for the needs of its consumers, which includes planning specific sales strategies for different consumers (Wardani, 2002).

The measurement of adaptive sales in shaping the ability of an adaptive sales force was initiated by (Spiro and Weitz 1990), including: (1) Knowledge structures that facilitate understanding of various sales situations and determining appropriate sales strategies, (2) Skills in gathering information on sales situations to facilitate adaptation and the use of various approaches in different situations, (3) Confidence in the ability to understand different sales situations that require different sales approaches, using various sales approaches or changing sales approaches. So that it can be further detailed that adaptive sales measurements are: (1) Recognition that different sales approaches are needed for different customers, (2) Confidence in the ability to use various approaches, (3) Confidence in the ability to change approaches during interactions, (4) Information gathering to facilitate adaptation, (5) Use of different actual approaches.

\section{Custumer Oriented}

Customer-oriented selling can be seen as a marketing concept practice at both the seller and customer level. In the concept of marketing, the cornerstone of marketing in recent years, requires an integrated approach, in which all company activities are directed at providing customer satisfaction and building long-term mutually beneficial relationships with its market (Kotler, 2000). Kurtz, Dodge, and Klompmaker (1976) explicitly link the marketing concept to salesperson behavior.

Customer-oriented selling is a way of doing business on the part of the sales force. This term refers to the degree to which a salesperson practices the concept of marketing by trying to help their customers make purchasing decisions that will satisfy the customer's needs. Salespeople who are highly customer-oriented engage in behaviors aimed at increasing long-term customer satisfaction. In addition, they avoid behavior that can lead to 
customer dissatisfaction. Thus, salespeople who are highly customer-oriented avoid actions that sacrifice customer interest in order to increase the likelihood of making direct sales. (Saxe and Weitz, 1982)

In an effort to improve the performance of the sales force, the company is constantly trying to find new approaches to making sales. These approaches stem from the existence of a selling orientation approach and a customer orientation approach (Saxe and Weitz, 1982). Selling Orientation or Sales Orientation is an activity that focuses more on sales activities that produce in the short term, compared to customer satisfaction which will form into consumer loyalty in the long term. Sujan et al. (1994) added that salespeople who use sales orientation are motivated to give maximum work results to prove their work to their colleagues or managers.

Another approach that can be used as a solution in improving sales force performance is customer orientation. The customer orientation approach argues that selling orientation can improve sales force performance, because salespeople who have a sales orientation only think how to get consumers to make purchases without being oriented to long-term relationships. Homburg et al., (2011) stated that customer orientation is a key variable in the marketing literature (Stock and Hoyer, 2009). Customer orientation illustrates the importance of understanding customer needs and starting to adapt their products and activities to meet those needs as effectively and efficiently as possible.

The twenty-four-item sales-customer-orientation (SOCO) scale, originally developed by Saxe and Weitz (1982), has been used in several studies in industrial and consumer areas. Several authors have suggested or made modifications to the scale by changing the wording of the items and/or by changing the number of items on the scale (Tadepalli 1995; Williams and Attaway 1996). Generally, however, these changes have been made to fit item wording to a particular setting or because of qualitative research showing that some items may not be appropriate rather than as an attempt to further refine the scale.

The SOCO scale developed by Thomas, Soutar and Ryan (2001) reduced SOCO which originally had 24 question items to 10 question items, this was done because of the consideration of filling time which took a lot of time to maintain 24 question items, meanwhile most of the salespeople were reluctant fill out the questionnaire if you see that there are many questions asked.

\section{Theoretical framework and hypotheses development}

Adaptive selling and customer orientation have been considered essential for a successful sales force. Although these topics have been frequently studied in the literature, most studies have been conducted in developed country settings and such studies are limited in other cultural contexts. Moreover, crosscountry/cultural comparisons of the role of adaptive selling and customer orientation are even rarer. Therefore, the aim of this study is to examine the role of adaptive selling and customer orientation on salesperson performance in two different markets in Europe and Asia - namely Finland and Macau. Using personal interviews, data was collected from salespeople operating in both countries. The results showed that customer orientation had a significant effect on sales performance, customer satisfaction, and adaptive sales behavior of salespeople. Furthermore, the adaptive sales behavior of salespeople has a significant effect on sales performance and customer orientation but not on customer satisfaction. (Kaynak, Kara, Chow \& Laukkanen, 2016)

The current personal selling literature shows that adaptive selling and customer orientation have been frequently researched by researchers and have attracted the interest of practitioners in the last three decades. In general, adaptive selling and customer orientation allow salespeople to tailor their sales message according to customer needs, expectations, and preferences. More specifically, adaptive selling involves understanding the sales situation and changing sales behavior in response to customer needs and wants, thereby leading to higher levels of customer orientation (Weitz, Sujan, \& Sujan, 1986). Siguaw (1991) argues that "the empathic relationship between the seller and the customer can also result from the adaptive selling process", thus suggesting that adaptive selling can be considered as an antecedent and consequence of customer orientation (Franke \& Park, 2006). Adapting to customers means focusing on their individual needs and preferences, leading to a higher level of customer orientation.

The selling skills of salespeople affect their ability to adapt their sales strategy during sales interactions (Weitz et al., 1986). The effect of selling skills on adaptive selling is exerted through the knowledge that sales staff use to evaluate sales situations and develop sales strategies for each customer (Weitz et al., 1986; Sharma et al., 2000). Recent studies provide support for this relationship between selling skills and performance. For example, Rentz et al. (2002) reported a significant positive correlation between the selling skills dimension and self-reported performance measures. Similarly, the research of Plouffe et al. (2009) show that selling skills are a significant predictor of people's performance. Wachner et al. (2009) and Pettijohn et al. (2007) further confirm the main effect of selling skills on subjective performance. 
This research model can be described as follows:

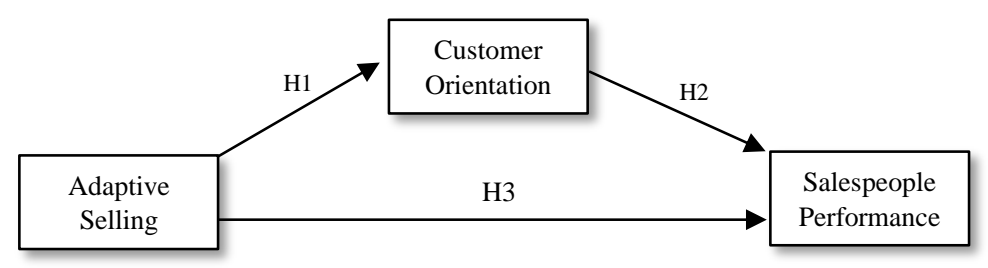

Hypotheses

H1: There is a direct effect of adaptive selling on customer orientation.

$\mathrm{H} 2$ : There is a direct effect of customer orientation on the performance of salespeople.

H3: There is a direct effect of adaptive selling on salesperson performance.

H4: Adaptive selling affects salesperson performance through customer orientation.

\section{Methode}

The population in this study is life insurance salespeople who already have a license as life insurance salespeople, which according to the Indonesian Life Insurance Association (AAJI) the number of licensed life insurance agents was 595,192 people in the first quarter of 2019. The sampling technique used in this study is non-probability sampling due to the large population and the researcher does not allow to have a sampling frame. Sampling was done by purposive sampling technique combined with snowball sampling. According to Sugiyono (2014) snowball sampling is a technique for determining samples that are initially small in number, then enlarge. According to Kriyantono (2014) purposive sampling is a sampling technique that provides certain criteria made by researchers based on research objectives.

In this study, the sample is life insurance salespeople who have at least 2 years of work experience as a life insurance seller, both female and male salespeople with unlimited education levels. While the number of samples in this study amounted to 278 people, and who met the requirements for processing were as many as 275 . This number has met the requirements according to Sekaran (2003) that the research sample using SEM can be used if the number is at least 150 .

\section{Result}

Factor Weight Significance Test

Used to determine whether a variable can be used to confirm that the variable can be together with other variables to explain a latent variable (Ferdinand; 2002: 168). The strength of these dimensions in forming the latent factor can be analyzed using a t-test on the regression weight generated by the model as presented in the estimation table for each variable. C.R or Critical Ratio is identical to t-count in regression analysis. From the table above, each variable has a C.R value that has met the requirements, which has a value above 2.58 and a probability $<0.05$. Therefore, C.R greater than 2.58 and probability $<0.05$ indicates that these variables are significantly dimensions or indicators of the latent variables formed.

Table 1 Summary of CFA Test Results $(n=275)$

\begin{tabular}{llrrrl}
\hline \multicolumn{1}{c}{ Variables } & RMSEA & GFI & TLI & CFI & Conclusion \\
\hline Adaptive Selling & 0.079 & 0.875 & 0.863 & 0.881 & Good Fit \\
Customer Orientation & 0.069 & 0.951 & 0.949 & 0.962 & Good Fit \\
Salesperson Performance & 0.037 & 0.990 & 0.993 & 0.996 & Good Fit \\
\hline
\end{tabular}

\section{Composite Reliability}

Test reliability is related to the measurement portion because of the permanent effect that persists from sample to sample (Netmeyer, Bearden, \& Sharma, 2003). Reliability analysis indicates the ability of a test to produce consistent scores (Friedenberg, 1995). High reliability indicates that the indicators have a very high consistency in measuring the latent construct.

There are several ways to measure reliability. In general, the estimation techniques used are test-retest, alternative forms, split-halves, and Croanbach's Alpha. Of the several estimation techniques, the fewest assumptions were found using Croanbach's Alpha (Wijanto, 2008). So to estimate the reliability of the congeneric measure, the alpha value gives an estimate that is too low (Bollen, 1989). In SEM, the composite reliability measure is used (Wijanto, 2008). 
Table 2 Combined Reliability $(\mathrm{n}=275)$

\begin{tabular}{lccc}
\hline \multicolumn{1}{c}{ Variables } & $\left(\sum \boldsymbol{\lambda}\right)^{\mathbf{2}}$ & $\left(\sum \boldsymbol{\theta}\right)$ & $\boldsymbol{\rho}_{\mathbf{c}}$ \\
\hline Adaptive Selling & 91,317 & 10,263 & 0,899 \\
Customer Orientation & 29,431 & 4,967 & 0,856 \\
Salesperson Performance & 12,47502 & 2,451 & 0,836 \\
\hline
\end{tabular}

Based on the results of the combined reliability calculation, all variables have a good level of reliability because they have a value of 0.60 . The highest combined reliability is on the adaptive selling variable, which is 0.899 .

Analysis of Direct Effects and Indirect Effects

The aim is to analyze the strength of the influence between constructs which consists of an analysis of direct and indirect effects. The direct effect is the coefficient of all the lines with one-pointed arrows. Indirect influence is the influence that arises through an intermediate variable (Ferdinand, 2002). The results of the direct effect test are stated in the following:

Table 3 Result of Direct Effect Calculation

\begin{tabular}{lrrr}
\hline Variables & $\begin{array}{c}\text { Adaptive } \\
\text { Selling }\end{array}$ & $\begin{array}{c}\text { Customer } \\
\text { Orientation }\end{array}$ & $\begin{array}{c}\text { Salesperson } \\
\text { Performance }\end{array}$ \\
\hline Customer Orientation &, 182 &, 000 &, 000 \\
Salesperson Performance &, 009 &, 254 &, 000 \\
\hline
\end{tabular}

Table 3 shows that the direct effect of Adaptive Salling on Customer Orientation is 0.182 and on Sales Force Performance (KTP) with a value of 0.009 . The direct effect of customer orientation on sales force performance (KTP) with a value of 0.254 .

Furthermore, the results of the indirect effect test are stated in the following table:

Table 4 Result of Indirect Effect Calculation

\begin{tabular}{lccc}
\hline \multicolumn{1}{c}{ Variables } & $\begin{array}{c}\text { Adaptive } \\
\text { Selling }\end{array}$ & $\begin{array}{c}\text { Customer } \\
\text { Orientation }\end{array}$ & $\begin{array}{c}\text { Salesperson } \\
\text { Performance }\end{array}$ \\
\hline Customer Orientation &, 000 &, 000 &, 000 \\
Salesperson Performance &, 046 &, 000 &, 000 \\
\hline
\end{tabular}

Based on table 4, it can be seen that the indirect effect of Adaptive Salling on Sales Force Performance is 0.046 .

Table 5 Summary of Hypothesis Test Results

\begin{tabular}{|c|c|c|c|c|c|c|}
\hline Hypothesis & Equation & $\begin{array}{c}\text { Stand. } \\
\text { estimate }\end{array}$ & C.R & P-Value & Result & Explanation \\
\hline $\mathrm{H} 1$ & $\begin{array}{l}\text { Adaptive Selling } \\
\rightarrow \text { Customer } \\
\text { Orientation }\end{array}$ & 0,182 & 2,618 & 0,009 & $\begin{array}{l}\text { Hypothesis } \\
\text { accepted }\end{array}$ & $\begin{array}{l}\text { There is an influence between the } \\
\text { Adaptive Selling on Customer } \\
\text { Orientation }\end{array}$ \\
\hline $\mathrm{H} 2$ & $\begin{array}{l}\text { Customer } \\
\text { Orientation } \rightarrow \\
\text { Salesperson } \\
\text { Performance }\end{array}$ & 0,254 & 3,498 & 0,000 & $\begin{array}{l}\text { Hypothesis } \\
\text { accepted }\end{array}$ & $\begin{array}{l}\text { There is a positive influence of } \\
\text { customer orientation on Salesperson } \\
\text { performance }\end{array}$ \\
\hline \multirow{2}{*}{$\begin{array}{l}\mathrm{H} 3 \\
\mathrm{H} 4\end{array}$} & $\begin{array}{l}\text { Adaptive Selling } \\
\rightarrow \text { Salesperson } \\
\text { Performance }\end{array}$ & 0,009 & 0,137 & 0,891 & $\begin{array}{l}\text { Hypothesis } \\
\text { rejected }\end{array}$ & $\begin{array}{l}\text { Adaptive Selling have no significant } \\
\text { effect on Salesperson Performance }\end{array}$ \\
\hline & $\begin{array}{l}\text { Adaptive Selling } \\
\rightarrow \text { Customer } \\
\text { Orientation } \rightarrow \\
\text { Salesperson } \\
\text { Performance }\end{array}$ & 0.046 & 2.089 & 0.036 & $\begin{array}{l}\text { Hypothesis } \\
\text { accepted }\end{array}$ & $\begin{array}{l}\text { Customer Orientation can mediate } \\
\text { the effect of Adaptive Selling on } \\
\text { Salesperson Performance }\end{array}$ \\
\hline
\end{tabular}




\section{Discussion}

There is a direct effect of adaptive selling on customer orientation.

The results showed that adaptive selling has a direct effect on customer orientation. This finding is in accordance with the results of research conducted by several researchers who stated that adaptive selling involves understanding the sales situation and changing sales behavior in response to customer needs and desires, thus leading to a higher level of customer orientation (Weitz, Sujan, \& Sujan, 1986). Siguaw (1991) argues that "...the empathic relationship between the seller and the customer can also result from the adaptive selling process", thus suggesting that adaptive selling can be considered as an antecedent and consequence of customer orientation (Franke \& Park, 2006).

There is a direct influence of customer orientation on the performance of salespeople.

In this study it can be argued that customer orientation can affect the performance of salespeople, which is in line with the findings of Sari (2014) which states that a good customer orientation can help improve sales performance. Sales performance is a dimension of sales performance. Good attention from salespeople to customers is reflected in the ability of salespeople to meet customer needs and solve customer problems by recommending suitable products to meet customer needs. The results of the study of Schwepker et al. (2012) Customer orientation has a positive and significant effect on the results of sales performance. Among them, sales performance is an indicator to measure the performance of salespeople.

Agustina (2016) found in her research that customer orientation has a positive and significant effect on sales force performance. This effect indicates that the more the seller can see things from the customer's perspective, the better the seller's performance will be.

There is no direct effect of adaptive selling on salesperson performance.

This study shows that there is no direct influence between adaptive sales on salesperson performance, but with the mediation of customer orientation it shows an indirect effect between adaptive sales and sales force performance. These results contradict the findings of Kara et al. (2013) which states that salespeople with a high level of adaptive sales will improve sales performance. The existence of this influence indicates that the higher the ability of the salesperson to use a different sales approach for each consumer, the higher the salesperson's performance.

Adaptive selling affects salesperson performance through customer orientation.

The findings in this study note that there is an influence between adaptive selling on sales force performance mediated by customer orientation. This is in line with research by Kaynak et al (2016) that adaptive selling and customer orientation are very important for a successful sales force. The results showed that customer orientation had a significant effect on sales performance, and sales force adaptive sales had a significant effect on sales performance and customer orientation.

The current personal selling literature shows that adaptive selling and customer orientation have been frequently researched by researchers and have attracted significant practitioner interest over the past three decades. In general, adaptive selling and customer orientation allow salespeople to tailor their sales message according to customer needs, expectations, and preferences. More specifically, adaptive selling involves understanding the sales situation and changing sales behavior in response to customer needs and wants, thereby leading to higher levels of customer orientation (Weitz, Sujan, \& Sujan, 1986). Siguaw (1991) argues that "...the empathic relationship between the seller and the customer can also result from the adaptive selling process", thus suggesting that adaptive selling can be considered as an antecedent and consequence of customer orientation (Franke \& Park, 2006). Adapting to customers means focusing on their individual needs and preferences, leading to a higher level of customer orientation. Furthermore, growing globalization and the need to maintain competitive advantage both internationally and domestically provide a strong need for management to understand the factors of salesperson performance in an international context. In addition, growing global economic and organizational integration requires managing the sales force across cultural and national boundaries.

In their research, Ramendra and Gopal (2012) obtained results by presenting the adaptive sales behavior of salespeople with sales performance through customer-oriented sales mediation. Although in the context of selling, declarative knowledge, and procedural knowledge increase with selling experience, partly explains the increase in sales performance (Weitz et al., 1986).

\section{Conclusion}

It can be concluded that adaptive sales have no direct effect on sales force performance, however, based on empirical data, it can be seen that adaptive sales affect sales force performance through customer orientation.

Because of the small, even direct effect between customer orientation and the performance of life insurance salespeople, life insurance companies should continue to improve their salespeople's understanding of 
the importance of customer orientation, by conducting training or training related to self-development and increasing competence as a life insurance salesperson.

The salesperson's performance appraisal in this study was carried out subjectively, namely based on the salesperson's self-assessment, so future research is recommended to add an objective assessment method (supervisor evaluation), namely the assessment carried out by the salesperson's superiors who are responsible for the performance of each salesperson. This allows the salesperson's performance data to be balanced because it is seen from two aspects, both personally and from the perspective of others who are responsible for the performance of each salesperson.

\section{Limitation}

The scope of the research should be done by making clusters based on marketing areas, both in big cities and in district cities, so that the research results can be generalized more broadly.

Besides that, research has not looked at more factors that can affect sales force performance, as shown in previous studies there are several factors that can affect sales force performance. Further research is expected to be able to see more factors that can influence and improve sales force performance, including emotional intelligence and interpersonal skills.

\section{Acknowledgements}

The researcher would like to thank the postgraduate program of Gunadarma University which has facilitated this research and do not forget to convey to all those who have helped a lot in the completion of the preparation of this research journal.

\section{References}

Agustina, L. (2016). Pengaruh Penjualan Adaptif, Kemampuan Mendengar dan Orientasi Pelanggan terhadap Kinerja Tenaga Penjual Jasa Hotel Bintang 4 dan 5 di Yogyakarta.

Alnawas, Ibrahim and Brown, Jane Hemsleybps, (2018). "The differential effect of cognitive and emotional elements of experience quality on the customer-service provider's relationship", International Journal of Retail \& Distribution Management. DOI 10.1108/IJRDM03-2017-0058

Aslam, Usman; Ilyas, Muhammad; Imran, Muhammad; Rahman, Ubaid. (2016). Intelligence and its impact on managerial effectiveness and career success (evidence from insurance sector of Pakistan). Journal of Management Development. DOI 10.1108/JMD-10-20150153

Asosiasi Asuransi Jiwa Indonesia (2020). Laporan Kinerja Industri Asuransi Jiwa, Kuartal III Tahun 2020

Babakus, E., Cravens, D.W., Grant, K., Ingram, T.N. and LaForge, R.W. (1996), Investigating the Relationships Among Sales Management Control, Sales Territory Design, Salesperson Performance, and Sales Organization Effectiveness. International Journal of Research in Marketing, Vol. 13, pp. 345-63

Bollen, Kenneth. A. 1989. Structural Equations with Latent Variables. Amerika: John Wiley \& Sons, Inc.

Churchill, Gilbert A., Neil M. Ford, Steven W. Hartley, and Orville C. Walker, Jr. (1985), The Determinations of Salesperson Performance: A Meta-Analysis. Journal of Marketing Research, 22 (May), 103-118.

ELSamen, Abu Amjad; Mamoun N. Akroush. (2018). How customer orientation enhances salespeople's performance? A case study from an international market. Benchmarking: An International Journal. Vol. 25 No. 7, pp. 2460-2477. Emerald Publishing Limited. DOI 10.1108/BIJ-05-2017-0101

F.L.Chung, H. (2011). Market Orientation, Guanxi, and Business Peformance. Elsevier Industrial Marketing Management, 40(4), 522-533. doi.org/10.1016/j.indmarman.2010.12.008

Franke, G. R., \& Park, J. E. (2006). Salesperson adaptive selling behavior and customer orientation: A meta-analysis. Journal of Marketing Research, 43(4), 693-702.

Friedenberg, Lisa. 1995. Psychological Testing : Design, Analysis and Use. Boston: Allyn \& Bacon.

Goolsby, J.R., Lagace, R.R., \& Booromis. (1992). Psychological Adaptiveness and Sales Performance. Journal of Personal Selling and Sales Management, 12 (2), 52-66.

Homburg, C., M. Müller, dan M. Klarmann. (2011). When does Salespeople's Customer Orientation lead to Customer loyalty? The Differential Effects of Relational and Functional Customer Orientation. J. of the Acad. Mark. Sci. 39:795-812.

Kara, A., Andaleeb, S. S., Turan, M., dan Cabuk, S. (2013). An Examination of The Effects of Adaptive Selling Behavior and Customer Orientation on Performance of Pharmaceutical Salespeople in An Emerging Market.

Kavoosi, Sara Samaneh Sadeghian dan Kolsum Mahmudi. (2014). An Empirical Investigation Of The Impact Of Customer Orientation, Adaptive Selling Behaviors, And Job Satisfaction On Salespeople's Performance: The Moderating Role of Selling Experience. International Journal of Research in Management, ISSN 2249-5908, Issue 4, Vol. 3 (May).

Kaynak, Erdener; Kara, Ali; Chow, Clement S. F. \& Laukkanen, Tommi (2016). Role of adaptive selling and customer orientation on salesperson performance: Evidence fromt wo distinct markets of Europe and Asia, Journal of Transnational Management.

Keillor, B.; Parker, R.; and Pettijohn, C. (2000). Relationship-Oriented Characteristic and Individual Salesperson Performance. Journal of Bussiness \& Industrial Marketing. 15 No.1: $7-20$.

Kotler, P. (2000). Marketing Management: Analysis, Planning, Implementation, and Control. 9 ${ }^{\text {th }}$ Edition. New Jersey: Prentice Hall International, Inc.

Kurtz, David L.; Dodge, H. Robert; Klompmaker, Jay E. 1979. Professional Selling. Business Publication

Manske, A.K., Glaeser, J., Kuypers, M.M.M., and Overmann, J. (2005) Physiology and phylogeny of green sulfur bacteria forming a monospecific phototrophic assemblage at a depth of 100 meters in the Black Sea. Appl Environ Microbiol 71: 8049-8060.

McIntyre, R.P., Wheatley, E.W., \& Uhr, E.B. (1996). Psychological Influences on Adaptive Selling Techniques in The Real Estate Sales Force. Journal of Professional Service Marketing.13(2), 137-150. 
Miti, Jairous Joseph; Perkio, Mikko; Metteri, Anna; Atkins, Salla. (2020). Factors associated with willingness to pay for health insurance and pension scheme among informal economy workers in low- and middle-income countries: a systematic review. International Journal of Social Economics. Vol. 48 No. 1, pp. 17-37. Emerald Publishing Limited. DOI 10.1108/IJSE-03-2020-0165

Netemeyer, R. G., Bearden, W. O., \& Sharma, S. (2003). Scaling procedures. SAGE Publications, Inc. https://www.doi.org/10.4135/9781412985772

Otoritas Jasa Keuangan, (2020). Statistik Perbankan Indonesia 2020. Otoritas Jasa Keuangan (OJK). Jakarta.

Park, Jeong Eun, and Deitz, George D. (2006). The Effect of Working Relationship Quality on Salesperson Performance and Job Satisfaction: Adaptive Selling Behavior in Korean Automobile Sales Representatives. Journal of Business Research 59 (2006) 204 - 213

Putri, Kusuma Nuzulul and Ernawaty, Ernawaty. (2020). Viral marketing content for Universal Health Coverage campaign in Indonesia. International Journal of Pharmaceutical and Healthcare Marketing. Vol. 14 No. 1, pp. 21-36. Emerald Publishing Limited. DOI 10.1108/IJPHM-07-2017-0041

Ramendra, Singh and Gopal Das. (2013) The impact of job satisfaction on salesperson's performance. Journal of Business \& Industrial Marketing. 28/7.

Sari, D. K. (2014). Smart Working Orientation dan Customer Orientation; Implikasinya terhadap Kinerja Tenaga Penjualan Multi Level Marketing.

Saxe, R. and Weitz, B. (1982). The SOCO Scale: A Measure of the Customer Orientation of Salespeople. Journal of Marketing Research, Vol. 19, August. 343-51.

Schwepker, C., dan D. J. Good. (2004). Sales Management Practices: The Impact of Ethics on Customer Orientation, Employment, and Performance. Marketing Management Journal 14 (Fall):133-146.

Sekaran, U. (2003) Research Methods for Business: A Skill-Building Approach. 4th Edition, John Wiley \& Sons, New York.

Siguaw, J. A. J. (1991). The relationship of customer orientation, adaptive selling and selected antecedents: A causal model (Doctoral dissertation). College of Administration and Business, Louisiana Tech University, Ruston, Louisiana

Spiro, R.L, \& Weitz, B.A. (1990). Adaptive Selling: Conceptualization, Measurement and Nomological Validity. Journal of Marketing Research, 28 (February), 61-69.

Stanton, W. (1999). Management of Sales Force. Singapore: Mc Graw Hill Book Company Inc.

Stock, R. M., dan W. D. Hoyer. (2009). An Attitude-Behavior Model of Salespeople's Customer Orientation. Journal of the Academy of Marketing Science. 33 (4):536-552.

Sujan, H., Weitz, B. A., \& Kumar, N. (1994). Learning Orientation, Working Smart, and Effective Selling. Journal of Marketing, 58(3), 3952. doi.org/10.1177/002224299405800303

Thomas, Raymond W., Sautar, Geoffrey N. \& Ryan, Maria M. (2001). The Selling Orientation-Customer Orientation (S.O.C.O.) Scale: A Proposed Short Form. Journal of Personal Selling \& Sales Management, 21:1, 63-69

Tseng, Lu-Ming. (2018). How customer orientation leads to customer satisfaction - Mediating mechanisms of service workers etiquette and creativity. International Journal of Bank Marketing. Vol. 37 No. 1, pp. 210-225. Emerald Publishing Limited. DOI 10.1108/IJBM10-2017-0222

Verbeke, W., Dietz, B., \& Verwaal, E. (2011). Drivers of sales performance: A contemporary meta-analysis. Have salespeople become knowledge brokers? Journal of the Academy of Marketing Science, 39(3), 407-428. doi.org/10.1007/s11747-010-0211-8

Weitz, Barton A, Harish Sujan, and Mita Sujan. (1986). Knowledge, Motivation, and Adaptive Behavior: A Framework for Improving Selling Effectiveness. Journal of Marketing, 50 (October), 174-191.

Wijanto, Setyo Hari, (2008), Structural Equation Modeling, Penerbit Graha Ilmu, Yogyakarta.

Wong, Kok-Leong; Cheng-Ling Tan. (2016). Influence Of Supervisory Control On Salesperson Performance: Examining The Role Of Adaptive Selling Behaviour As A Mediator. Asian Academy of Management Journal, Vol. 21, No. 2, $183-203$.

Yu, Tsu-Wei and Chen, Mei-Su. (2014). Developing life insurer-insurance intermediary relationships. Managing Service Quality Vol. 24 No. 5, 2014 pp. 455-468. Emerald Group Publishing Limited. DOI 10.1108/MSQ-09-2013-0181

Yudiani, Ema. (2005). Hubungan Antara Kecerdasan Emosi dan Masa Kerja dengan Penjualan Adaptif. PSIKOLOGIKA Nomor 19, tahun X, Januari. 